\title{
Do (Audit Firm and Key Audit Partner) Rotations Affect Value Relevance? Empirical Evidence from the Italian Context
}

\author{
Alessandro Mechelli ${ }^{1}$, Riccardo Cimini ${ }^{1}$ \\ ${ }^{1}$ DEIM, University of Tuscia, Viterbo, Italy \\ Correspondence: Riccardo Cimini, DEIM, University of Tuscia, Viterbo, Via Santa Maria in Gradi, 4-01100, \\ Italy.E-mail: rcimini@unitus.it
}

Received: November 11, 2016

Accepted: December 7, 2016 Online Published: December 16, 2016

doi:10.5539/ibr.v10n1p143

URL: http://dx.doi.org/10.5539/ibr.v10n1p143

\begin{abstract}
This research aims to investigate whether and to what extent investors place more weight on accounting amounts disclosed in annual reports issued by entities that experienced a rotation of the audit firm or of the key audit partner. Analysing a sample of 97 non-financial entities listed in the Milan stock exchange over the period 2006-2014, the paper provides evidence that rotations positively affect the value relevance of accounting amounts. In addition, the paper shows how the audit firm rotation and the key partner rotation act only in part as substitutes, as the former is more capable than the latter of positively affecting the value relevance of earnings and book value. These results provide a theoretical contribution to the literature and have significant implications for standard setters. The rotations, even though could determine a loss of client-specific knowledge, nonetheless improve the value relevance of accounting amounts. New rules that require the key partner rotation have a positive effect as long as they do not consider such rotation as an alternative to the rotation of the audit firm being the partner rotation less capable to affect the value relevance of accounting amounts than the key audit firm rotation.
\end{abstract}

Keywords: audit firm rotations, key audit partner rotations, value relevance, Ohlson model

\section{Introduction}

The objective of this research is to verify whether the rotations of audit firm and of the key audit partner positively affect the value relevance of earnings and book value disclosed in annual reports of non-financial listed entities. The paper also studies whether and to what extent the audit firm and the key partner rotations are interchangeable in terms of the ability to affect the weight investors place on earnings and book value.

The main motivations behind the study of this topic are twofold. First, Bamber and Bamber (2009) explain that there is a real need for scientific evidence on the extent to which rotations yield benefits, given the loss of client-specific knowledge (due to rotations) that potentially impairs the effectiveness and quality of the audit. Second, we reason that the information that could be deduced, directly or indirectly, from the auditing opinion makes accounting amounts more reliable (complete, neutral and free from error) and relevant (useful) for investors to predict future earnings and cash flow.

In the accounting literature, scholars have investigated the ability of the different information contained in the auditing report to affect audit quality (e.g., Manry et al., 2008; Lennox et al., 2014) or financial reporting quality (Litt et al., 2014), providing different arguments justifying results that, in many cases, contradict each other. A limited number of studies deepen the contribution that such information provides to the weight that investors place on accounting amounts. Few papers focus on audit firm rotations (Robu et al., 2016) or test whether they affect the value relevance of accounting amounts. Conversely, to the best of our knowledge, no papers have investigated whether the key audit partner rotations affect value relevance or to what extent it is interchangeable with audit firm rotation.

According to the first hypothesis of this research, because rotations are signals (Spence, 1973) of independence against earnings management behaviours, investors should place more weight on accounting amounts disclosed in annual report issued in the year when the audited firm experienced a rotation of the audit firm or of the audit partner. This is because earnings and book value - audited by a new independent auditor - are perceived to be more reliable and so more relevant (Barth et al., 2001) compared with those disclosed by entities that do not 
experienced rotations. Even if we expect that both the audit firm and the key partner rotation positively affect the value relevance of accounting amounts, we believe that it is not reasonable to expect that they are perfectly interchangeable, as the audit firm rotation is more capable of affecting the value relevance of accounting amounts than the key partner rotation. Reasons for this can be found in Bamber and Bamber (2009), according to whom audit partner rotation is likely to yield second-order effects relative to the effects of audit firm rotation.

To study the effect of rotation on the value relevance of accounting amounts, the present study analyses a sample of 97 Italian non-financial listed entities, investigated over the period of 2006-2014. Value relevance has been assessed using a modified version of the price model (Ohlson, 1995) with variables deflated by the number of outstanding shares. The model includes, between the explicative variables, several interaction terms that control for the presence of a switch of the audit firm or of the key audit partner. These variables allow for testing whether divergence of value relevance between entities that experienced and did not experience rotations is statistically significant. Running regressions over the period analysed, the research results validate our hypotheses. The paper provides evidence that rotations positively affect the value relevance of accounting amounts. However, the audit firm rotation seems to be more capable than the partner rotation of influencing the weight that investors place on accounting amounts.

Findings contribute to the literature because they provide first evidence of how not only the audit firm rotation but also the partner rotation improves the value relevance of accounting amounts. In addition to validating the theoretical assumption that rotations are signals (Spence, 1973), the paper provides evidence about how audit firm rotations could be considered "strong" signals while the partner rotations are "weak" signals for investors. As a consequence, standard setters, issuing or amending the auditing standards, should be aware of the importance of rotations to increase the quality of financial reporting at least in terms of improving the reliability and thus the value relevance of accounting amounts. They also should consider that the rules on partner rotation cannot substitute for those of audit firm rotation for the different effects of such rules on the weight investors place on accounting amounts in supporting their investment strategies.

The paper proceeds as follows. Section 2 is dedicated to the literature review and to the development of the research hypotheses. Section 3 describes the research methodology followed to test the research hypotheses. Section 4 presents the sample selection strategy and descriptive statistics. Section 5 contains the main research findings. Finally, section 6 concludes the paper, including limitations and directions for further developments.

\section{Literature Review and Hypotheses Development}

The term "value relevance" refers to the ability of accounting amounts to reflect the underlying economic value of a firm (Hung \& Subramanyam, 2007), measured by stock market prices as a synthesis of market participants' beliefs about future cash flows and discount rates; therefore, accounting amounts are value relevant if they are associated with stock prices, and value relevance research assesses how well accounting amounts reflect information that investors use (Barth et al., 2001). In the accounting literature, value relevance is considered a dimension of accounting quality (Barth et al., 2008; Chen et al., 2010), together with earnings management and conservatism, and can be grounded in the so-called positive accounting theory (PAT) stream of research that is considered an explanation for observed accounting and auditing practices.

There are few value relevance studies within the audit field of research, especially regarding the usefulness of information that investors can find in auditing reports to benefit for their investment strategies. Such information is not incorporated in earnings and book value. However, it helps investors to better understand accounting amounts, thus increasing their value relevance, particularly if such information is useful to form reasonable beliefs about the persistence of earnings, the risks entities will face in the future, the strategies entities can use to counterbalance them, and so on. According to Nilsson (2003), other information sources such as analysts' forecasts might be more timely than current accounting figures. In addition, non-financial information might be more relevant than accounting information for valuation.

The main categories of information that could be perceived, directly or indirectly, in the auditing reports and that could affect the value relevance of accounting amounts include:

a) type of auditor (Big 4 vs. not Big 4);

b) auditor opinion;

c) auditor tenure;

d) rotations (of audit firm or of the key audit partner).

The type of auditor can be found directly in the auditing report. This tends to be the information most often 
investigated by scholars in the value relevance field of research. Scholars find that entities audited by Big 4 auditors are also those with the lowest cost of capital (Karjalainen, 2011) and those that provide a higher level of assurance and credibility (Hsien - Li \& Hua, 2013) to lead investors to perceive accounting amounts audited by these audit firms more value relevant. In this regard, for the Taiwan market, Hsien - Li and Hua (2013) show that earnings and book value of equity audited by Big 4 auditors explain more variations in stock returns than those audited by non-Big 4 auditors. Similarly, Mihai (2016) and Dobre and Brad (2015), investigating a sample of Romanian listed companies find that the value relevance of accounting amounts disclosed by entities audited by Big 4 auditors is higher compared with those of entities audited by non-Big 4 auditors. Different results have been found by Robu \& Robu (2015); analysing 59 Romanian listed companies observed over the period 2012-2013, the scholars found that the auditor's affiliation to the Big 4 group that releases a clean opinion does not have a significant influence on the relevance of the audited information. They argue that this is due to the need to respect the same audit standards and professional guidelines, irrespective of the size and the notoriety of the auditing company.

Like the name of the auditor, the audit opinion can also be found in the auditing report itself. According to Ittonen, (2012), the audit opinion increases the users' trust in the reported information and plays a basic role in the communication process between them and the company. As is the case with the type of auditor, there is an open debate in the literature about the usefulness of the auditor opinion. Karjalainen (2011) found that Finnish firms with modified audit reports have low quality accruals and high cost of debt capital. In the same vein, the results of Robu \& Robu (2015) show that the reported earnings at the end of the financial exercise and for which an unqualified opinion was issued are positively associated with the share prices. This is true only for earnings, as the scholars found that a clean opinion does not affect the value relevance of book value of equity. Using the Tunisian market over the period of 2000-2005 as a reference, Hakim and Omri (2012) showed that accounting information value relevance is associated with the reputation, experience, and specialisation of the external auditors. Focusing on qualified opinion and, in particular, going-concern opinions, Blay et al. (2011) found that the market valuation is significantly altered from a focus on both the income statement and the balance sheet to a balance sheet-only focus in the year a company receives a first-time going-concern modified opinion. This is due to the fact that entities that receive such opinions are distressed entities, with the book value of the equity that, incorporating the liquidation option, is more useful for investors compared with the reported earnings. There are also scholars who found no evidence about the relation between the auditor opinion and the value relevance of accounting amounts. Analysing 156 companies listed on the Tehran Stock Exchange (TSE) over a period of 10 years, Banimahd et al. (2013) found that unqualified audit reports and other audit reports do not differ in the capital market.

Information regarding tenure is not found directly in a single auditing report. It is necessary to observe more reports over time to understand how long the same audit firm is working for the same client. Banimahd et al. (2013) found that when the tenure of auditors is long, it has a negative impact on the value relevance of accounting amounts. Assuming auditor tenure as a proxy of the independence of the auditor, the higher the tenure is, the more probable it is that opportunistic behaviours due to familiarity between the audit company and the audited company could make accounting amounts less reliable and relevant for investors' decisions. Although such arguments are convincing, there are scholars that find no relations between the value relevance of accounting amounts and tenure (Hakim \& Omri, 2012). Other scholars, like Ghosh and Moon (2005), find that longer audit firm tenure is associated with greater value-relevance of reported earnings. Similarly, among studies that investigate the effect of tenure on audit quality, Manry et al. (2008) find that audit quality appears to increase with increased partner tenure. This finding is consistent with other studies (Geiger \& Raghunandan, 2002; Johnson et al., 2002; Myers et al., 2003; Nagy, 2005) and also extends their findings by focusing on individual audit partners rather than on audit firms. Also Litt et al. (2014) observe low financial reporting quality following an audit partner change. Specifically, they find low financial reporting quality during the first two years with a new audit partner relative to the final two years with the outgoing partner.

Focusing on rotations, in the literature there are very few value relevance studies about audit firm rotations. In this regard, Robu et al. (2016) focused on 64 Romanian companies listed on the Bucharest Stock Exchange between 2006 and 2014. They found that the auditor's rotation significantly contributes to the change of the value relevance degree. This result should suggest that the length of the auditor mandate is inversely associated with the weight investors place on earnings and book value. In fact, rotation is a characteristic that enhancing the perceived independence of the auditor should provide confidence to investors toward the relevance and the reliability of accounting amounts other than, according to Salehi et al. (2009), the reliability of the auditors' reports. Rotations do not involve only the audit firm but also the key audit partner, yet in the literature there is a 
lack of focus on the effect that such rotations have on the value relevance of accounting amounts. However, some scholars have investigated more general aspects, such as the capability of partner rotation to positively affect earnings quality. For instance, Chi et al. (2009) investigate the effectiveness of mandatory audit partner rotation in promoting audit quality in Taiwan, using both abnormal accruals and earnings response coefficients as a proxy for audit quality. Although their findings suggest that the audit quality of entities subject to mandatory audit-partner rotation in 2004 is higher than the audit quality of companies not subject to rotation in 2004, they find no difference between the audit quality of firms that experienced a mandatory rotation and that of those clients not subject to mandatory rotation or those whose audit partners rotated voluntarily. This conclusion led Bamber and Bamber (2009) to consider Chi et al. (2009) a "no-result" paper, which, nevertheless, made a significant contribution to the accounting literature. More recently, Lennox et al. (2014) find that mandatory rotation of engagement partners results in high quality audits in the years immediately following rotation, supporting the thesis that the pros of partner rotation on audit quality (positive peer review effect and a fresh perspective on the audit) outweigh the cons (loss of client-specific knowledge).

To formulate a plausible research hypothesis about the effect of rotations (of the audit firm and of the key audit partner) on the value relevance of accounting amounts, we have to consider rotations as a proxy of the independence of the auditor (Blandón Garcia \& Argilés Bosch, 2013). Such independence should prevent collusive behaviours between the auditors and the managers, due to the familiarity with the client that is typical of a long audit tenure, and should increase the quality of monitoring activity against opportunistic behaviours of managers. It is from the PAT that we learn that, within the companies, managers use to select accounting procedures to maximize their utility functions. Because managers have flexibility to choose from a set of accounting policies in the face of changing circumstances, they will choose discretion for their own benefits, which opens the door for opportunistic behaviour ex post (Rath \& Sun, 2008). The independence of the auditor, preventing opportunistic behaviours, should increase investors' perception of the reliability of accounting amounts, assuming reliability typical of information that is complete, neutral and free from error (IASB, 2010). In this regard, focusing on Irish companies, Kilcommins (1997) argues that independence and the reliability of financial statements were perceived to be significantly impaired when: the audit was performed by a non-Big Six firm, the audit environment was highly competitive, no audit committee existed, audit tenure was long, non-audit services were provided by audit personnel to audit clients, or the auditor took up an employment position with a former audit client. In this sense, investors, in presence of rotations that enhance the independence of the auditor, should consider accounting amounts more reliable - that is, more unaffected by earnings management behaviours. Thanks to the rotations, accounting amounts should be not only more reliable but also more relevant; that is, they should be more useful for making a decision, in the event that they are capable of making a difference in that decision (IASB, 2010). These considerations regarding the independence that rotations guarantee lead us to formulate the first hypothesis of this research:

\section{$H_{1}$ : The rotations of the audit firm or of the key audit partner increase the value relevance of accounting} amounts.

The second objective of this paper is to verify whether audit firm rotation and partner rotation could be considered substitutes in affecting the value relevance of accounting amounts. To formulate a plausible research hypothesis, we have to consider rotations like signals to be useful to increase the public's confidence in audited financial statements and to rekindle a national debate on auditor independence and audit quality (Chi et al., 2009). According to the theoretical framework of Spence (1973), signals are observable characteristics attached to an individual that are subject to manipulation by that individual. Thus, the audit firm rotation is a signal that the audited firm conveys to investors that have to select the best firms to which to allocate their capital. This signal should convince them that an independent auditor analyses, reviews, and develops an auditing opinion asserting the relevance and the faithfulness of the audit firm's financial statements for external users. Thanks to audit firm rotation, investors should perceive accounting amounts to be value relevant (Robu et al., 2016). Key partner rotation also acts as a signal. However, unlike the audit firm rotation, it is conveyed by the audit firm to investors with the primary aim of enhancing credibility toward the auditor activity. Such rotation contributes to enhance the value relevance of accounting amounts only indirectly, consistent with the insight of Bamber and Bamber (2009), according to whom audit partner rotation is likely to yield effects that are second-order relative to the effects of audit firm rotation. In this regard, these scholars explain that in audit firm rotation, the new firm brings a new audit team, applies the (new) firm's own audit methodology, and also applies additional new client procedures. In audit partner rotation, in most cases all that changes is just the audit partner. Thus, audit partner rotation can improve independence if problems arise from the individual partner and the new engagement partner significantly influences the rest of the audit team, but partner rotation cannot solve independence problems 
arising from audit firm culture. Audit partner rotation is less likely to compromise audit team competence than partner rotation, because other elements of the audit team and technology remain in place, and legal liability increases incentives for the outgoing partner and the national office to train and monitor the incoming partner. This leads us to hypothesize that audit firm rotation and partner rotation are not perfect substitutes in affecting the value relevance of accounting amounts. For this reason, the signal conveyed by the client to rotate the audit firm prior to the legal term of its mandate could be considered a "strong" signal that is better able to affect the value relevance of earnings and book value compared with the key partner rotation, which could be considered a "weak" signal. Therefore, the second research hypothesis of this research is as follows:

$\mathrm{H}_{2}$ : The audit firm and the key audit partner rotations act only in part as substitutes, as the former is better able than the latter to positively affect the value relevance of accounting amounts.

\section{Methodology}

To verify whether the audit firm and the key audit partner rotations affect the value relevance of accounting amounts, this paper uses the modified version of the price model (Ohlson, 1995) with variables deflated by the number of shares. This alleviates biases in the research results due to the presence in the analysed sample of entities of different sizes (Barth \& Clinch, 2009). Using a regression model for panel data and assuming the statistically significant regression coefficients as a measure of value relevance (Van Cauwenberge \& De Beelde, 2007), the equation that this research uses to test $H_{1}$ is as follows:

$$
\begin{aligned}
\mathrm{P}_{\mathrm{it}}= & \alpha_{0}+\alpha_{1} \mathrm{NIPS}_{\mathrm{it}}+\alpha_{2} \mathrm{BVPS}_{\mathrm{it}}+\alpha_{3} \mathrm{ROT}_{\mathrm{it}}+ \\
& +\alpha_{4} \mathrm{ROT}_{\mathrm{it}} \mathrm{XNIPS}_{\mathrm{it}}+\alpha_{5} \mathrm{ROT}_{\mathrm{it}} \mathrm{XBVPS}_{\mathrm{it}}+\alpha_{\mathrm{t}-1} \mathrm{~T}+\alpha_{\mathrm{s}-\mathrm{l}} \mathrm{S}+\varepsilon_{\mathrm{it}}
\end{aligned}
$$

where:

$P_{i t}$ represents the price-per-share of firm $i$ at the $t$ fiscal-year end;

$N I P S_{i t}$ is net income per-share of firm $i$ at the $t$ fiscal-year end;

$B V P S_{i t}$ is book value of equity per-share of firm $i$ at the $t$ fiscal-year end;

$R O T_{i t}$ is a dummy that assumes a value of 1 if a change of the audit firm or of the key audit partner is observed in the audit opinion attached to the consolidated annual reports issued by entity $i$ at the end of fiscal-year $t$;

$T$ and $S$ are dummies that identify the $t-1$ years analysed and the $s-1$ industries analysed.

This specification allows for measuring the value relevance of earnings and book value reported in annual reports of entities that have not experienced any rotation; in addition, it provides a measure of the divergences in value relevance of accounting amounts disclosed by entities that experienced the rotation of the audit firm or of the key audit partner. In particular, the regression coefficients $\alpha_{1}$ and $\alpha_{2}$, if statistically significant, are a measure of value relevance of earnings and book value disclosed by entities that, in a certain year, have not experienced either audit firm rotation or key audit partner rotation. Instead, the coefficients of the interaction terms $\left(\alpha_{4}\right.$ and $\left.\alpha_{5}\right)$ measure the difference between the weight that investors place on accounting amounts disclosed by entities that experienced and did not experience a rotation. The expectation is to find them to be positive and statistically significant. The positive sign means that in entities that experienced rotations, accounting amounts are more value relevant; the statistical significance of coefficients means that the value relevance of accounting amounts is different between firms that experienced and did not experience rotations. To strengthen our findings about such differences, the research protocol tests the null hypothesis that coefficients $\alpha_{3}, \alpha_{4}$ and $\alpha_{5}$ are jointly all equal to zero. If the test rejects this hypothesis, the research provides further evidence that there is a structural break (Chow, 1960) in the regression coefficients that measure the value relevance of earnings and book value between the groups of entities that experienced and did not experience a rotation over the period analysed. Therefore, if the regression coefficients of interaction terms are positive and statistically significant and the test rejects the null hypothesis mentioned above, we have enough evidence to support the hypothesis that investors place more weight on accounting amounts disclosed by entities that have experienced a rotation than on those disclosed by entities that have not.

Once it has been verified that rotations positively affect the value relevance of accounting amounts, this research investigates whether or not the audit firm and the key audit partner rotations are interchangeable. To do so, we split the variable ROT, and its interactions, into two dummy variables that distinguish audit firm rotations (AFR) from key partner rotations (KPR). The equation used to test the second hypothesis is as follows: 


$$
\begin{aligned}
& \mathrm{P}_{\mathrm{it}}=\alpha_{0}+\alpha_{1} \mathrm{NIPS}_{\mathrm{it}}+\alpha_{2} \mathrm{BVPS}_{\mathrm{it}}+\alpha_{3} \mathrm{AFR}_{\mathrm{it}} \mathrm{xNIPS} \mathrm{it}_{\mathrm{it}}+\alpha_{4} \mathrm{KPR}_{\mathrm{it}} \mathrm{xNIPS} \mathrm{it}_{\mathrm{it}}+ \\
& +\alpha_{5} \mathrm{AFR}_{\mathrm{it}} \mathrm{xBVPS} \mathrm{Sit}_{\mathrm{it}}+\alpha_{6} \mathrm{KPR}_{\mathrm{it}} \mathrm{xBVPS} \mathrm{it}_{\mathrm{it}}+\alpha_{7} \mathrm{AFR}_{\mathrm{it}} \alpha_{8} \mathrm{KPR}_{\mathrm{it}}+\alpha_{\mathrm{t}-1} \mathrm{~T}+\alpha_{\mathrm{s}-1} \mathrm{~S}+\varepsilon_{\mathrm{it}}
\end{aligned}
$$

where:

$A F R_{i t}$ is a dummy that assumes a value of 1 if a change of the audit firm is observed in a given year;

$K P R_{i t}$ is a dummy that takes a value of 1 if, within the same task to an audit firm, in a given year there has been a change of the audit partner.

Compared with equation (1), equation (2) includes, between the explicative variables, dummies that control for a switch of the audit firm (AFR) and of the audit partner (KPR), whose name is available on the audit opinion attached to the consolidated annual report of the analysed entities. Taking into account the meaning of the interaction terms (e.g., difference between the value relevance of accounting amounts disclosed by entities that experienced and did not experience a rotation), like ROT $\mathrm{it}_{\mathrm{it}} \mathrm{XNIPS}$ it and $\mathrm{ROT}_{\mathrm{it}} \mathrm{xBVPS}$, the expectation is to find them to be positive and statistically significant, for the reasons explained above. Nevertheless, to validate the second research hypothesis (i.e., audit firm and the audit partner rotations act only in part as substitutes, as the former is better able than the latter to positively affect the value relevance of accounting amounts) two further conditions are required. First, concerning the value relevance of earnings, $\alpha_{3}$ should be higher than $\alpha_{4}$; in addition, regarding book value of equity, $\alpha_{5}$ should be higher than $\alpha_{6}$. These expected results provide first evidence that the value relevance of accounting amounts is higher in the case of audit firm rotation than in the case of partner rotation. Second, the difference between $\alpha_{3}$ and $\alpha_{4}$ (regarding the positive effect of rotations on earnings) and between $\alpha_{5}$ and $\alpha_{6}$ (regarding the positive effect of rotations on book value) should be statistically significant. If this is the case, the paper provides evidence that audit firm rotation is better able than partner rotation to affect the value relevance of accounting amounts and thus that such rotations are not perfectly interchangeable in terms of the effects on the value relevance of accounting amounts.

\section{Sample Selection and Descriptive Statistics}

The data required to implement the methodology described above refer to Italian entities listed over the period of 2006-2014 in the Milan stock exchange. The price per-share and the accounting amounts have been downloaded from the Amadeus database, while the name of the audit firm and of the key audit partner have been hand-collected from the consolidated annual reports available on the websites of the entities analysed. According to the Amadeus database, the number of entities with available data over the period analysed is 137; the final sample contains 97 entities. Exclusions include entities that do not end their fiscal year on $31^{\text {st }}$ December, in line with scholars involved in value relevance studies (e.g., Tsalavoutas et al., 2012), and those for which the audit opinions were not available in at least one of the years analysed. In this regard, the audit opinions from fiscal year 2005 have also been collected in order to verify entities that in 2006 rotated the audit firm or simply the key audit partner. Before presenting the descriptive statistics and the research results, it may be useful to note that $85 \%$ of the annual reports prepared by the analysed entities have been audited by a Big 4 audit company, while the remaining $15 \%$ have been audited by non-Big 4 entities. Also, $98 \%$ of the annual reports analysed received a clean opinion, $0.6 \%$ received a qualified opinion, and $1.4 \%$ received an adverse opinion containing the "going-concern" exception.

In Table 1, we tabulate the main descriptive statistics of variables used to test the research hypotheses.

Table 1. Descriptive statistics

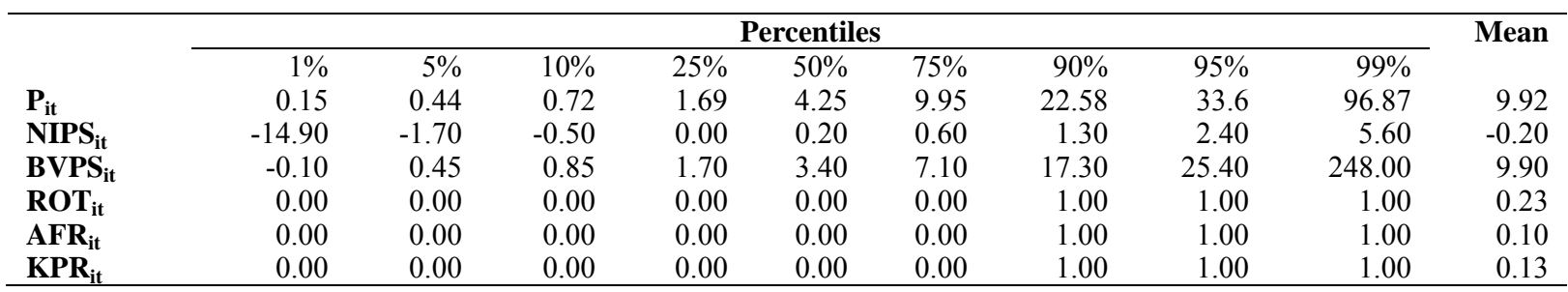

The table provides interesting insights about the rotations. Over the period analysed, about $23 \%$ of the entities experimented a rotation, which involved the audit firm in $10 \%$ of the cases and the key audit partner in the other $13 \%$.

Table 2 tabulates the correlation coefficients among the variables used to test our hypotheses. 
Table 2. Correlation matrix

\begin{tabular}{|c|c|c|c|c|c|c|c|c|c|c|}
\hline & $=$ & $\begin{array}{l}\ddot{n} \\
\hat{\Sigma}\end{array}$ & $\sum_{n}^{\dot{n}}$ & $\stackrel{:}{0}$ & $\frac{\vec{v}}{4}$ & $\underline{\vec{z}}$ & 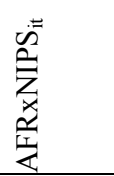 & $\begin{array}{l}\dot{n} \\
\hat{n} \\
\ddot{n} \\
\underline{a} \\
\underline{a}\end{array}$ & 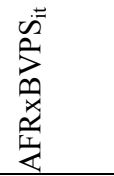 & 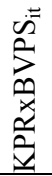 \\
\hline$\overline{P_{i t}}$ & 1 & & & & & & & & & \\
\hline NIPS $_{i t}$ & -0.03 & 1 & & & & & & & & \\
\hline $\mathrm{BVPS}_{\mathrm{it}}$ & $0.63^{* * *}$ & $-0.10^{* * *}$ & 1 & & & & & & & \\
\hline $\mathrm{ROT}_{\mathrm{it}}$ & 0.01 & 0.02 & 0.02 & 1 & & & & & & \\
\hline $\mathrm{AFR}_{\mathrm{it}}$ & 0.02 & 0.01 & 0.01 & $0.63^{* * *}$ & 1 & & & & & \\
\hline $\mathrm{KPR}_{\mathrm{it}}$ & -0.01 & 0.01 & 0.02 & $0.69^{* * *}$ & $-0.12^{* * *}$ & 1 & & & & \\
\hline $\mathrm{AFRxNIPS}_{\mathrm{it}}$ & $0.12^{* * *}$ & $0.12^{* * *}$ & $0.07^{* *}$ & 0.04 & $0.06^{*}$ & -0.01 & 1 & & & \\
\hline $\mathrm{KPRxNIPS}_{\text {it }}$ & $0.27^{* * *}$ & $0.07^{* *}$ & $0.26^{* * *}$ & $0.17^{* * *}$ & $0.26^{* * *}$ & -0.03 & $0.57^{* * *}$ & 1 & & \\
\hline AFRxBVPS $_{\text {it }}$ & 0.04 & $0.16^{* * *}$ & $0.07^{* *}$ & 0.01 & -0.01 & 0.02 & 0.01 & 0.001 & 1 & \\
\hline $\mathrm{KPRxBVPS}_{\text {it }}$ & $0.10^{* * *}$ & $0.08^{* *}$ & $0.23^{* * *}$ & $0.22^{* *}$ & -0.03 & $0.31^{* * *}$ & -0.01 & -0.004 & $0.51^{* * *}$ & 1 \\
\hline \multicolumn{11}{|c|}{$\begin{array}{l}\text { Mean VIF of equations } 1 \text { and } 2: 1.19 \text { and } 1.21 \\
\text { Correlation coefficients different from zero at } 1 \%\left(^{* * *}\right), 5 \%\left({ }^{* *}\right) \text { and } 10 \%\left(^{*}\right) \text { level of significance }\end{array}$} \\
\hline
\end{tabular}

\section{Research Findings}

Tables 3 and 4 below tabulate the main findings of our analysis that are useful to test our two research hypotheses.

Table 3. Findings (equation 1)

\begin{tabular}{|c|c|c|c|c|}
\hline & Predicted signs & Coefficients & P-value & \multirow{6}{*}{ 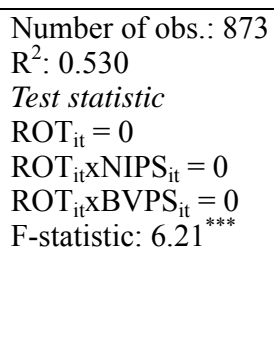 } \\
\hline $\mathrm{NIPS}_{\text {it }}$ & + & +0.14 & +0.001 & \\
\hline $\begin{array}{l}\mathrm{BVPS}_{i t} \\
\mathrm{ROT}_{\text {it }}\end{array}$ & $\begin{array}{l}+ \\
+\end{array}$ & $\begin{array}{l}+1.81 \\
-1.08\end{array}$ & $\begin{array}{l}+0.000 \\
+0.307\end{array}$ & \\
\hline ROTxNIPS $_{\text {it }}$ & + & +0.63 & +0.012 & \\
\hline ROTxBVPS $_{\text {it }}$ & + & +0.07 & +0.033 & \\
\hline Intercept & $+/-$ & +3.35 & +0.410 & \\
\hline
\end{tabular}

$(\stackrel{* * *}{*})$ Value statistically significant at $1 \%$

Table 3 validates our first research hypothesis, which states that investors place more weight on earnings and book value disclosed by entities that have experienced a rotation. The regression coefficient that measures the value relevance of earnings $\left(\right.$ NIPS $\left._{i t}\right)$ of the first group of entities that have not experienced any rotation is +0.14 . The regression coefficient of earnings for the second group of entities that experienced a rotation is +0.77 , and thus the divergence in value relevance between the groups of entities $\left(\right.$ ROTxNIPS $\left._{\text {it }}\right)$ is positive and statistically significant (+0.63). Similarly, the regression coefficient that measures the value relevance of book value (BVPS $\left.{ }_{i t}\right)$ of the first group of entities that have not experienced any rotation is +1.81 . The regression coefficient of book value for the second group of entities that have experienced a rotation is +1.88 , and thus the divergence in value relevance between these groups of entities $\left(\right.$ ROTxBVPS $\left._{i t}\right)$ is positive and statistically significant $(+0.07)$. In testing the significance of the difference between the value relevance of earnings and the book value of the two groups of entities, the results of the test statistic tabulated in Table 3 show that the null hypothesis that such difference is not statistically significant is rejected at the $1 \%$ level. So, the findings tabulated in Table 3 also suggest that the weight that investors place on accounting amounts disclosed by entities that have experienced a rotation is not only higher than but also statistically different from the weight placed on accounting amounts disclosed by entities that have not experienced a rotation. Once we verified that rotations have these desirable effects, we tested whether the audit firm rotation is better able than the key partner rotation to positively affect the value relevance of accounting amounts. In this regard, table 4 below presents the research findings useful to test the second research hypothesis. 
Table 4. Findings (equation 2)

\begin{tabular}{|c|c|c|c|c|}
\hline & Predicted signs & Coefficients & P-value & \multirow{3}{*}{$\begin{array}{l}\text { Number of obs.: } 873 \\
R^{2}: 0.537\end{array}$} \\
\hline NIPS $_{\text {it }}$ & + & +0.14 & +0.001 & \\
\hline $\mathrm{BVPS}_{\mathrm{it}}$ & + & +1.82 & +0.000 & \\
\hline $\mathrm{AFRxNIPS}_{\mathrm{it}}$ & + & +0.93 & +0.029 & \multirow{2}{*}{$\begin{array}{l}\text { Test: AFRxNIPS }{ }_{i t}-\text { KPRxNIPS }_{\text {it }} \\
\text { F-statistic: } 4.38^{* *}\end{array}$} \\
\hline $\mathrm{KPRxNIPS}_{\text {it }}$ & + & +0.74 & +0.017 & \\
\hline $\operatorname{AFRxBVPS}_{i t}$ & + & +0.10 & +0.011 & \multirow{5}{*}{$\begin{array}{l}\text { Test: } \text { AFRxBVPS }_{\text {it }}-\mathrm{KPRxBVPS}_{\mathrm{it}} \\
\text { F-statistic: } 4.03^{* *}\end{array}$} \\
\hline $\mathrm{KPRxBVPS}_{\text {it }}$ & + & -0.06 & +0.275 & \\
\hline $\mathrm{AFR}_{\mathrm{it}}$ & + & -0.45 & +0.753 & \\
\hline $\mathrm{KPR}_{\mathrm{it}}$ & + & -0.75 & +0.586 & \\
\hline $\begin{array}{l}\text { Intercept } \\
\left(^{* *}\right) \text { Value stat }\end{array}$ & $\begin{array}{l}+/- \\
\text { significant at } 5 \%\end{array}$ & +3.34 & +0.687 & \\
\hline
\end{tabular}

The table validates our second research hypothesis that audit firm rotation and key partner rotation act only in part as substitutes, affecting the value relevance of accounting amounts in different manners. Regarding the value relevance of earnings, the regression coefficient in entities that have not experienced a rotation $\left(\mathrm{NIPS}_{\mathrm{it}}\right)$ is +0.14 . In entities that experienced the audit firm rotation, the coefficient is +1.07 , while in entities that experienced the key audit partner rotation, the coefficient is +0.88 . The divergence between the value relevance of earnings in entities that experienced the audit firm rotation and that of earnings in entities that did not experience rotation is +0.93 (see AFRxNIPS it $_{\text {it }}$ ) and is statistically different from zero at $5 \%$. The divergence between the value relevance of earnings in entities that experienced a key audit partner rotation and that of earnings in entities that did not experience rotation is +0.74 (see KPRxNIPS ${ }_{i t}$ ) and is statistically different from zero at $5 \%$. Therefore, the positive effect of the audit firm rotation is higher than the positive effect of the key partner rotation. The test statistic tabulated in Table 4 shows that the difference between the coefficients of AFRxNIPS $_{i t}$ and $\mathrm{KPRxNIPS}_{\mathrm{it}}$ is statistically different from zero at $5 \%(\mathrm{~F}$-statistic $=4.38)$. Regarding the value relevance of book value, the regression coefficient in entities that have not experienced rotation $\left(\mathrm{BVPS}_{\mathrm{it}}\right)$ is +1.82 . In entities that experienced the audit firm rotation, the coefficient is +1.92 , while in entities that experienced the key audit partner rotation, it is +1.82 . In fact, while the divergence between the value relevance of book value in entities that experienced the audit firm rotation versus those that did not experience rotation is +0.10 (see AFRxBVPS $_{\mathrm{it}}$ ) and is statistically different from zero at $5 \%$, the divergence between the value relevance of book value in entities that experienced and did not experience rotations of the partner is 0 , indicating that KPRxNIPS ${ }_{\text {it }}$ is not statistically significant. Therefore, for the value relevance of book value of equity, the positive effect of the audit firm rotation is higher than the effect (null) of the key partner rotation. The test statistics tabulated in Table 4 show that the difference between AFRxBVPS ${ }_{i t}$ and KPRxBVPS ${ }_{i t}$ is statistically different from zero at 5\% (F-statistic $=4.03)$. Findings tabulated in Table 4 also show that disaggregating ROT in AFR and KPR rotations positively affects the value relevance of accounting amounts in most of the cases. Nevertheless, the results unanimously suggest that investors place more weight on earnings and book value when entities switch the audit firm rather than the key audit partner. This result validates the reasoning of our hypothesis that these forms of rotation act only in part as substitutes, consistent with the insight of Bamber and Bamber (2009) that audit partner rotation is likely to yield effects that are second-order compared with the effects of audit firm rotation.

\section{Conclusions}

The aim of this research is to verify the effect of both the audit firm and the key partner rotation on the value relevance of accounting amounts. Even though the literature is quite consistent in recognizing the positive effect of audits on the financial reporting quality, different results arise when investigating the effect of audit firm rotation on the value relevance of accounting amounts. In fact, there are two opposite effects that occur following the rotation. The first is the increase in reliability due to the limitation of opportunistic behaviours, while the second is the reduction of the loss of client-specific knowledge. Therefore, doubts arise regarding the combined effect of rotations on the value relevance of accounting amounts. In addition, no papers have investigated the effect of the key audit partner rotation on value relevance and the possibility that such a rotation could be considered a substitute of the audit firm rotation.

By using a sample of 97 Italian listed companies investigated over the period of 2006-2014, our research reached two results. The first result is that the increase of the reliability of accounting amounts due to rotations, both of the audit firm and of the partner, increases the value relevance of accounting amounts. The second result is that, as expected, the two kinds of rotations - audit firm and key partner - are not perfect substitutes. In fact, even though both rotations are signals, only the change of the audit firm implies a full change of the team, with new people and 
new procedures, while the change of the key partner often is limited to the substitution of a single person.

Our results have implications for both researchers and regulators. For scholars, our paper adds to the existing literature, both on the real effect of two kinds of rotations on the value relevance of accounting amounts and on the possibility of considering them as substitute. With reference to regulators, our results show that the rotations, even though could determine a loss of client-specific knowledge, nonetheless improve the value relevance of accounting amounts. However, new rules that require the key partner rotation have a positive effect as long as they do not consider such rotation as an alternative to the rotation of the audit firm.

Regarding limitations, we should consider that the need to hand-collect data implies that our analysis is limited to a single country. Future research could extend the investigation to other countries. However, the kind of variables we investigated should ensure that results we found in Italy are not influenced by individual country characteristics.

\section{References}

Bamber, E. M., \& Bamber, L. S. (2009). Discussion of "Mandatory Audit Partner Rotation, Audit Quality, and Market Perception: Evidence from Taiwan". Contemporary Accounting Research, 26(2), 393-402. https://doi.org/10.1506/car.26.2.3

Banimahd, B., Poorzamani, Z., \& Ahmadi, S. A. (2013). The Value Relevance of Audit report, Auditor Type and Auditor Tenure: Evidence from Iran. Asian Journal of Finance \& Accounting, 5(1), 89-103. http://dx.doi.org/10.5296/ajfa.v5i1.2787

Barth, M. E., \& Clinch, G. (2009). Scale Effects in Capital Markets-Based Accounting Research. Journal of Business Finance \& Accounting, 36(3-4), 253-288. https://doi.org/10.1111/j.1468-5957.2009.02133.x

Barth, M. E., Beaver, W. H., \& Landsman, W. R. (2001). The Relevance of the Value-Relevance Literature for Financial Accounting Standard Setting: Another View. Journal of Accounting and Economics, 31(1), 77-104. http://dx.doi.org/10.1016/S0165-4101(01)00019-2

Barth, M. E., Landsman, W. R., \& Lang, M. H. (2008). International Accounting Standards and Accounting Quality. Journal of Accounting Research, 64(3), 467-498. https://doi.org/10.1111/j.1475-679X.2008.00287.x

Blandón, G. J., \& Argilés Bosch, J. M. (2013). Audit tenure and audit Qualifications in a low litigation risk setting: An analysis of the Spanish market. Estudios De Economia, 40(2), 133-156. http://dx.doi.org/10.4067/S0718-52862013000200002

Blay, A. D., Geiger, M. A., \& North, D. S. (2011). The Auditor's Going-Concern Opinion as a Communication of Risk. Auditing: A Journal of Practice and Theory, 30(2), 77-102. http://dx.doi.org/10.2308/ajpt-50002

Chen, H., Tang, Q., Jiang, Y., \& Lin, Z. (2010). The Role of International Financial Reporting Standards in Accounting Quality: Evidence from the European Union. Journal of International Financial Management and Accounting, 21(3), 220-278. https://doi.org/10.1111/j.1467-646X.2010.01041.x

Chi, W., Huang, H., Liao, Y., \& Xie, H. (2009). Mandatory audit partner rotation, audit quality, and market perception: Evidence from Taiwan. Contemporary Accounting Research, 26(2), 359-391. https://doi.org/10.1506/car.26.2.2

Chow, G. C. (1960). Tests of equality between sets of coefficients in two linear regressions. Econometrica, 28(3), 591-605. https://doi.org/10.2307/1910133

Dobre, F., \& Brad, L. (2015). A Research Regarding the Influence of Financial Audit and of Corporate Governance on Value Relevance. Audit Financiar, 13(131), 116-126.

Geiger, M., \& Raghunandan, K. (2002). Auditor Tenure and Audit Reporting Failures. Auditing: A Journal of Practice and Theory, 21(1), 67-78. http://dx.doi.org/10.2308/aud.2002.21.1.67

Ghosh, A., \& Moon, D. (2005). Auditor tenure and perceptions of audit quality. The Accounting Review, 80(2), 585-612. http://dx.doi.org/10.2308/accr.2005.80.2.585

Hakim, I. H., \& Omri, M. A. (2012). Quality of the external auditor and value relevance of accounting information: case of the listed Tunisian companies. International Journal of Technology, Policy and Management, 12(1), 79-97. http://dx.doi.org/10.1504/IJTPM.2012.044970

Hsien,L. L., \& Hua, L. (2013). Do Big 4 audit firms improve the value relevance of earnings and equity? Managerial Auditing Journal, 28(7), 628-646. http://dx.doi.org/10.1108/MAJ-07-2012-0728

Hung, M., \& Subramanyam, K. R. (2007). Financial statement effects of adopting international accounting 
standards: the case of Germany. Review of Accounting Studies, 12(4), 623-657. https://doi.org/10.1007/s11142-007-9049-9

IASB (2010). Conceptual Framework for Financial Reporting.

Ittonen, K. (2012). Market reactions to qualified audit reports: research approaches. Accounting Research Journal, 25(1), 8-24. http://dx.doi.org/10.1108/10309611211244483

Johnson, V., Khurana, I., \& Reynolds, J. (2002). Audit-Firm Tenure and the Quality of Financial Reports. Contemporary Accounting Research, 19(4), 637-660. https://doi.org/10.1506/LLTH-JXQV-8CEW-8MXD

Karjalainen, J. (2011). Audit Quality and Cost of Debt Capital for Private Firms: Evidence from Finland. International Journal of Auditing, 15(1), 88-108. https://doi.org/10.1111/j.1099-1123.2010.00424.x

Kilcommins, M. (1997). Perceptions of auditor independence and the effects on the perceived reliability of financial statements in Ireland (Doctoral dissertation, Aberystwyth University).

Lennox, C. S., Xi, W., \& Tianyu, Z. (2014). Does Mandatory Rotation of Audit Partners Improve Audit Quality? Accounting Review, 89(5), 1775-1803. http://dx.doi.org/10.2308/accr-50800

Litt, B., Sharma, D. S., Simpson, T., \& Tanyi, P. N. (2014). Audit partner rotation and financial reporting quality. Auditing: A Journal of Practice \& Theory, 33(3), 59-86. http://dx.doi.org/10.2308/ajpt-50753

Manry, D. L., Mock, T. J., \& Turner, J. L. (2008). Does increased audit partner tenure reduce audit quality? Journal of Accounting, Auditing \& Finance, 23(4), 553-572.

Mihai, C. A. R. P. (2016). Empirical Study regarding the Influence of the Quality of Financial Information on the Value of Listed Companies. Audit Financiar, 14(133), 15-24.

Myers, J., Myers, L., \& Omer, T. (2003). Exploring the Term of the Auditor-Client Relationship and the Quality of Earnings: A Case for Mandatory Auditor Rotation? The Accounting Review, 78(3), 779-799. http://dx.doi.org/10.2308/accr.2003.78.3.779

Nagy, A. (2005). Mandatory Audit Firm Turnover, Financial Reporting Quality, and Client Bargaining Power: The Case of Arthur Andersen. Accounting Horizons, 19(2), 51-68. http://dx.doi.org/10.2308/acch.2005.19.2.51

Nilsson, H. (2003). Essays on the value relevance of financial statement information. Doctoral thesis.

Ohlson, J. A. (1995). Earnings, book values, and dividends in equity valuation. Contemporary Accounting Research, 11(2), 661-688. https://doi.org/10.1111/j.1911-3846.1995.tb00461.x

Rath, S., \& Sun, L. (2008). The development of earnings management research. International Review of Business Research Papers, 4(2), 265-277.

Robu, I., \& Robu, M. (2015). Statistical Analysis of the Audit Opinion influence on the Value Relevance of the Financial information. Audit Financiar, 13(131), 73-81.

Robu, I., Grosu, M., \& Istrate, C. (2016). The Effect of the Auditors' Rotation on the Accounting Quality. Audit Financiar, 14(133), 3-67. https://doi.org/10.20869/AUDITF/2016/133/65

Salehi, M., Mansoury, A., \& Azary, Z. (2009). Audit independence and expectation gap: Empirical evidences from Iran. International Journal of Economics and Finance, 1(1), 165-174. http://dx.doi.org/10.5539/ijef.v1n1p165

Spence, M. (1973). Job Market Signaling, The Quarterly Journal of Economics, 87(3), 355-374. https://doi.org/10.2307/1882010

Tsalavoutas, I., André, P. \& Evans, L. (2012). The transition to IFRS and the value relevance of financial statements in Greece. The British Accounting Review, 44(4), 262-277. http://dx.doi.org/10.1016/j.bar.2012.09.004

Van Cauwenberge, P., \& De Beelde, I. (2007). On the IASB comprehensive income project: an analysis of the case for dual income display. Abacus, 43(1), 1-26. https://doi.org/10.1111/j.1467-6281.2007.00215.x

\section{Copyrights}

Copyright for this article is retained by the author(s), with first publication rights granted to the journal.

This is an open-access article distributed under the terms and conditions of the Creative Commons Attribution license (http://creativecommons.org/licenses/by/4.0/). 